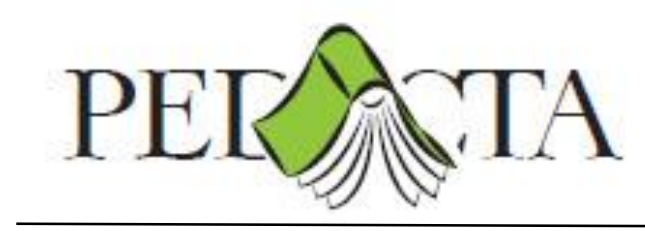

\title{
MEDDIG ÉLSZ MÉG VISSZA A TÜRELMÜNKKEL KORONAVÍRUS?
}

\section{QUO USQUE TANDEM ABUTERE, CORONAVIRUS, PATIENTIA NOSTRA?}

\author{
Tódor Imre
}

\begin{abstract}
According to the European Council conclusions on effective teacher training, both initial teacher education and the continuous professional development of teachers should be based on sound pedagogical research. At the basis of the problem of research and the question lies the desk research of the results of the 2018 TALIS international teacher research carried out by the OECD. TALIS can be considered as the most important source of information concerning the opinions and observations of teachers and school leaders related to education, professional situation as well as school environment. I seek to achieve all this by analysing the following dimensions: the TALIS sets of data regarding the question of the "preparation" of teachers, schools and the education system for digital education: digital equipment, ICT among the contents of teacher education, the presence of ICT in the professional training offer, teaching-learning supported by ICT tools. I compare the database selected for Romania (BTGROUT3) to the international data (TALIS-48, OECD-31, EU-23), while I use the Hungarian (BTGHUNT3) data as reference.
\end{abstract}

Keywords: TALIS 2018, digital education, Romania, ICT for teaching, ICT skills

\section{Bevezetés}

A tanulmány címe a méltán leghíresebb ókori római szónok, Marcus Tullius Cicero, Lucius Sergius Catilina ellen mondott négy beszéde közül az elsőnek a nyitómondata, pontosabban annak parafrazálása, ugyanis itt a Catilina fogalom helyett a Coronavirus szerepel. Magyar fordítása úgy hangzik: Meddig élsz még vissza a türelmünkkel koronavírus? Cicero a szenátusban felharsanó, mindent elsöprő, kiváló retorikai bravúrral megírt és elöadott beszéde az ellen a szenátortársa ellen irányul, aki a köztársaságot akarta megsemmisíteni, aki a hatalmat erőszakos úton akarta megszerezni, aki az államot képviselő köztisztviselőt meg akarta ölni, aki alattomos módon és eszközökkel korteskedett a pártja körében, aki hazug ígéretekkel és individuális, mégis látszólag a közérdeket szolgáló kampánybeszédével akarta a római népet és a szenátust meggyőzni. De nem sikerült! Olyan ellenszerrel kellett megküzdenie, amelyre nem volt felkészülve, Ciceróval.

Az elmúlt hat hónap világszerte konstatált legnagyobb „ellensége” a mindenhová magát beférkőző koronavírus, amely a világ minden szegletét, a társadalom, a társadalmi élet minden szegmensét, minden korosztályát megcélozta, így többek között az oktatást, valamint annak közvetlen és közvetett felhasználóit is. Tény, hogy a „vírusnak” nem sikerült az oktatást teljesen megbénítania, ugyanis a digitális-technológiai eszközök, a digitális pedagógia „személyében” olyan „ellenlábasra” talált, ahol nem győzedelmeskedhetett. Mindezek ellenére a pedagógusok, oktatási szakértők, szülők, tanulók, az oktatáspolitika, a politikum kérdése: meddig élsz még vissza a türelmünkkel „koronavírus”? Meddig élsz még vissza a türelmünkkel digitális oktatás, távoktatás, online oktatás? 
Jelen tanulmány fő kérdése az, hogy fel volt-e készülve az oktatás, az iskola, a pedagógusok, a tanulók, az oktatáspolitika, és minden oktatásban érintett aktor a jelenlegi virózisos állapotban megjelenő alternatív, bár sokak számára mégis újdonságnak számító trendre, azaz a digitális oktatásra/ távoktatásra/ online oktatásra, annak módszereire, eszközeire, gondolkodásmódjára, átállására? Nem spekulációval és eszmefuttatással, hanem a kész adatok másodelemzésével kívánom a kérdéskört körbejárni, nevezetesen olyan megbízható pedagógiai kutatáson alapuló vizsgálattal, mint a TALIS, mely az egyetlen, tanárokról készített, nemzetközi kutatás az elmúlt évtizedben.

\section{Módszer}

A TALIS ${ }^{1}$ vizsgálatot az OECD $^{2}$ végzi 5 évenként, amelyre legelőször 2008, majd 2013, és harmadik alkalommal 2018-ban került sor. Románia az első, míg Magyarország a 2013-as mérésben nem vett részt. A nemzetközi kutatás az ISCED 2-es szinten oktató tanárokat és az iskolavezetőket célozza meg, így két kérdőív - egy a tanárok, míg a másik a tanintézményvezetők körében - kerül lekérdezésre. ${ }^{3}$

A tanári kérdőív az utolsó, 2018-as, mérésen kilenc nagy témaköre 58 kérdést foglalt magában. A kutatás a következő nagyobb témakörökre fókuszált: tanárok demográfiai háttere és képesítése, az aktuális munkájára vonatkozó kérdések, szakmai továbbfejlődése, a tanári munkára kapott visszajelzések (feedback) és a tanári munka értékelése, a tanításról általában, a tanításról egy konkrét osztályban, a tanításról változatos környezetben, a tanári mobilitás stb. A tanintézményvezetői (igazgatói) kérdőív nyolc nagy témaköre 45 kérdést tartalmazott. A kutatás a következő nagyobb témakörökre fókuszált: igazgatók demográfiai háttere, az általa irányított iskola hátterére vonatkozó kérdések, az iskolavezetésre, a tanárok hivatalos értékelésére, az iskolai légkörre, az indukciós programokra és a mentorálásra, a munkával való elégedettségre stb. vonatkozó kérdéskörök (Ainley és Carstens, 2018).

Az utóbbi mérésen a mintába 48 ország került be, megduplázva a tíz évvel korábbi mérésben résztvevő országok számát (2008-ban 24 ország képviseltette magát, míg 2013-ban 34 ország). A központilag meghatározott mintavételi módszertan értelmében minden országból véletlenszerüen $\mathrm{kb}$. 200 ISCED 2-es szintü iskola kerül be a mintába, és iskolán belül pedig ugyanúgy véletlenszerủen 20 tanár. Így országonként kb. 4000 tanár és kb. 200 intézményvezető képezi az országos mintát. Romániából az utóbbi mérésen 3658 tanár és 199 tanintézményvezető került lekérdezésre, míg Magyarországon 3245 tanár és 182 igazgató. Nemzetközi összesítésben kb. 150000 tanár és 9000 intézményvezetö kerülne be. Az utóbbi mérésen a kérdőívet 153682 tanár és 9247 intézményvezetö töltötte ki. Az OECD hivatalos weboldalán elérhető a kutatás adatbázisa, amelyek közül az SPSS kiterjedésủ adatbázist (SPSS 2018 national, és SPSS 2018 international) használtam a tanulmány fő forrásaként, másodelemzés gyanánt. ${ }^{4}$

\footnotetext{
${ }^{1}$ Teaching and Learning International Survey kifejezés szókezdő betűinek a rövidítése. Magyar fordítása: Nemzetközi Tanítás és Tanulási Vizsgálat. A továbbiakban: TALIS 2018.

${ }^{2}$ OECD (Organisation for Economic Co-operation and Development - Gazdasági Együttműködési és Fejlesztési Szervezet), melyhez 36 tagállam tartozik - vö. http://www.oecd.org. A vizsgálatot az OECD INES (Nemzetközi Indikátor Munkacsoport) kezdeményezte, melynek lebonyolítását egy nemzetközi konzorcium végezte (IEA Adatfeldolgozó Központ, Hollandia és Németország; ACER, Auszrália; Kanadai Statisztikai Hivatal). A kutatás romániai adminisztrálását a 838/2015ös számú kormányrendelet (Hivatalos Közlönyben megjelent: 759/12.10.2015) értelmében a CNEE (Centrul Național de Evaluare și Examinare = Országos Értékelési és Vizsgáztató Központ) keretén belül létrehozott TALIS Országos Központ végezte. vö. Tódor, 2017, 159.

${ }^{3}$ Az ISCED (International Standard Classification of Education angol kifejezés rövidítése, magyarul: Az oktatás egységes nemzetközi osztályozási rendszere) az OECD (ahogyan az UNESCO és az Eurostat) egyik fontos oktatásstatisztikai harmonizációjának az eszköze, amely által össze tudja hasonlítani a különböző országok oktatáspolitikáját, eredményeit, helyzetét. A 2011-es, legújabb módszertana szerint nyolc szintet különítettek el az óvodai oktatástól a felsőfokú képzés doktorátusi szintjéig. Az ISCED 2-es szint Romániában az általános iskolai tagozatnak felel meg (5-8. osztály). vö. OECD/Eurostat/UNESCO Institute for Statistics, 2015.

${ }^{4}$ https://www.oecd.org/education/talis/talis-2018-data.htm. BTGINTT3 jelentése: B = Lower secondary education (ISCED level 2); $\mathrm{T}=$ Teachers; $\mathrm{G}=$ General questionnaire; INT $=$ International (TALIS-average); $\mathrm{T} 3$ = Third round of TALIS (TALIS 2018). A továbbiakban: TALIS 2018 adatbázis. A Romániára szelektált adatbázis jelzése: BTGROUT3, ahol a ROU Romániát jelzi, ahogyan a Magyarországra szelektált adatbázis jelzése: BTGHUNT3, ahol a HUN Magyarországot jelzi, a többi rövidítés megegyezik a fentebb leírtakkal. Néhány országban nemcsak az ISCED 2, hanem az ISCED 1 és ISCED 3 , valamint a PISA-TALIS link (nevezetesen kilencben) felmérést is elvégezték.
} 
Feltevéseink a nemzetközi empirikus kutatások talaján állnak (vö. OECD: TALIS), amelyeket az eddigi tereptapasztalataink által a következőképpen egészíthetünk ki. Azt feltételezzük, hogy azon pedagógusok, akik az oktatási tevékenységük során már korábban is az önállóan végzett tevékenységeket (digitális pedagógia, projektpedagógia, kollaboratív, problémaalapú stb. módszerek) részesítették előnyben, azok számára az új oktatásszervezési formára történő „átállás” gördülékenyebb és hatékonyabb volt. Azt feltételezzük, hogy az IKT eszközök tantermi használata szoros összefüggésben áll a pedagógus nemével, a szakmában eltöltött évek számával, valamint a tanárképzés és/vagy továbbképzések során tanult tartalmakkal, mint pl. IKT eszközökkel támogatott oktatás.

\section{A nemzetközi tanárvizsgálat eredményeinek másodelemzése és értelmezése}

A továbbiakban a tanári kérdőív néhány kérdésére adott válaszainak elemzését hajtom végre. ${ }^{5} \mathrm{~A}$ kérdőívben szereplő 58 kérdés közül - a tanulmány terjedelmi szempontjainak a figyelembevételével az IKT-eszközök oktatásban történő alkalmazását érintő kérdésekre adott válaszok elemzését hajtom végre, amelyek a pedagógusok digitális eszközhasználatára, képzettségére, készségeire, valamint az iskolák eszközellátottságára vonatkoznak.

O tempora, o didacticae! azaz Ó idők, ó didaktikák! Jelen kifejezés ismételten az ominózus In Catilinam első beszédéből - kissé átalakított formában - származik, amely immáron szállóigévé vált az évszázadok során. Az új időkhöz, új eszközök, új módszerek, új didaxisok kellenek; szentírási megfogalmazásban az új bor új tömlőbe. Vajon fel volt-e, fel van-e készülve az oktatáspolitika, a didaktika, az iskola, a tanárok, a tanulók a digitális oktatásra? Hipotetikus válaszom az, hogy feltehetően nem. Miért is nem? Mert nem volt eddig szükség rá? Mert megszoktuk és otthonosan érezzük magunkat a jól bevált és megszokott hagyományos üzemmódban? Mert nem (kevésbé) hatékony? Mert nem ismertük? Mert egyszerüen nem láttuk értelmét? A digitális oktatás, vagy annak különbözö, vele kapcsolatban álló válfajai, mint pl. a távoktatás ebben a szükségállapotban szükségszerü megoldásnak tüntek, tünnek. Valahogyan úgy képzelem el, mint egy balul sikerült lépés közben bekövetkezett bokaficam utáni mankóval való járásmódot. Nem a megszokott, nem kényelmes, nem az igazi, nem tetszik, de hasznos, amíg teljesen fel nem épülünk a sérülésünkböl, amelytől (mankótól) gyógyulásunk után azon nyomban megszabadulhatunk. Vajon mi történik az oktatásban? Teljesen megszabadulunk majd a digitális oktatástól, távoktatástól, online oktatástól, és csupán (kellemetlen, de szükségszerü) emlékként örizzük majd emlékeinkben, avagy szervesen beépítjük a meglévő módszertani, pedagógiai, didaktikai tárházunkba? Annyi bizonyos, hogy a szükségállapot a digitális oktatásnak, távoktatásnak az akcelerációját idézte elő. Nehéz elképzelni, hogy másképp a mainstream-be oly gyorsan be lehetett volna azt ültetni. A továbbiakban az eszközellátottságra vonatkozó kérdések megválaszolását elsősorban a TALIS ide vonatkozó adataiból igyekszem megválaszolni.

1. táblázat. A tanítási-tanulási folyamatot hátráltató tényezők $(\%)^{6}$

\begin{tabular}{|l|c|c|c|c|c|}
\hline & $\begin{array}{c}\text { TALIS } \\
\mathbf{( 4 8 )}\end{array}$ & $\begin{array}{c}\text { OECD } \\
(\mathbf{3 1})\end{array}$ & $\begin{array}{c}\text { EU } \\
(\mathbf{2 3})\end{array}$ & RO & HU \\
\hline $\begin{array}{l}\text { Hiányos vagy nem megfelelö digitális eszközök a } \\
\text { tanításhoz }\end{array}$ & 28,1 & 24,6 & 27,4 & $\mathbf{4 9 , 8}$ & 36,1 \\
\hline $\begin{array}{l}\text { A sajátos nevelési igényű tanulók oktatásához értő tanárok } \\
\text { hiánya }\end{array}$ & 31,2 & 32,1 & 37,8 & $\mathbf{4 5 , 1}$ & 35,2 \\
\hline Hiányos vagy nem megfelelö termek a tanításhoz & 26,6 & 25 & 27,3 & $\mathbf{4 4 , 3}$ & 26,2 \\
\hline Hiányos vagy nem megfelelö tananyagok & 15,6 & 12,9 & 17,2 & $\mathbf{4 1 , 5}$ & 20,2 \\
\hline
\end{tabular}

\footnotetext{
5 A TALIS kutatás teljeskörü elemzését egyrészt a nemzetközi jelentések (OECD, 2019; 2020), másrészt az országos jelentésekből (RO: Raport Național TALIS 2018, 2020; TALIS 2018, 2019; HU: Balázsi és Vadász, 2019) lehet nyomon követni.

${ }^{6}$ A TALIS 2018 tanintézményvezetői kérdőív 29. kérdése. A négyfokú skála 3. és 4. értékeit (eléggé és nagyon) összevontam.
} 


\begin{tabular}{|l|c|c|c|c|c|}
\hline Hiányos vagy nem megfelelő infrastruktúra & 27,1 & 25,5 & 27,6 & $\mathbf{3 9 , 8}$ & 33,2 \\
\hline Hiányos vagy nem megfelelö könyvtári felszereltség & 19,4 & 15,8 & 17,8 & $\mathbf{3 7 , 7}$ & 21,4 \\
\hline $\begin{array}{l}\text { A szakmai készségek fejlesztéséhez szükséges tanagyagok } \\
\text { és felszerelések hiánya vagy nem megfelelö volta }\end{array}$ & 20,9 & 18,1 & 19,1 & $\mathbf{3 6 , 6}$ & 23,8 \\
\hline Nem megfelelö internet-hozzáférés & 22,9 & 19,2 & 21,7 & $\mathbf{3 6 , 2}$ & 25 \\
\hline A pedagógusok munkáját segítő szakemberek hiánya & 30,8 & 32,6 & 38,4 & 35,7 & 41,8 \\
\hline Szakoktatók hiánya & 19 & 15,6 & 16,4 & 33,4 & 1,8 \\
\hline Szakképzett tanárok hiánya & 22,2 & 21 & 24,6 & 32,6 & 29,2 \\
\hline $\begin{array}{l}\text { Az oktatással kapcsolatos döntésekre fordítandó idő } \\
\text { hiánya vagy elégtelensége }\end{array}$ & 29,7 & 31,9 & 34,9 & 31,7 & 37,8 \\
\hline A tanulókra fordítandó idő hiánya vagy elégtelensége & 23,8 & 25,1 & 28 & 28,9 & 43,9 \\
\hline $\begin{array}{l}\text { Olyan tanárok hiánya, akik a szocio-ökonómiailag } \\
\text { hátrányos helyzetú háztartásból származó diákokat } \\
\text { képesek tanítani }\end{array}$ & 17,9 & 17,2 & 24,2 & 27 & 17,4 \\
\hline $\begin{array}{l}\text { Olyan tanárok hiánya, akik multikulturális vagy } \\
\text { többnyelvü környezetben képesek tanítani }\end{array}$ & 21,2 & 20,3 & 23,5 & 21,9 & 15,7 \\
\hline
\end{tabular}

Forrás: OECD, TALIS 2018 (BCGINTT3) - egyéni számítás és szerkesztés Chi-négyzet próba. Megj.: $p \leq 0,001$.

Az első fokos kérdés az, hogy az iskola (intézmény, tanárok, tanulók) rendelkezik-e a digitális oktatáshoz szükséges eszközökkel? A tanintézményvezetői kérdőív idevonatkozó kérdésére érkező válaszok értelmében meglehetősen nem (vö. 1. tábálázat adatsorai). Látható, hogy Romániában az igazgatók véleménye szerint a legnagyobb hiány épp a tanításhoz szükséges digitális eszközök hiányában rejlik. ${ }^{7}$ Akár az EU-s, az OECD-s, vagy a TALIS országok átlagainak a vizsgálata során azt látjuk, hogy szignifikánsan magasabb hiánnyal küszködünk. Gyakorlatilag az iskolák fele rendelkezik adekvát digitális eszközellátottsággal. A szomszédos Magyarország ellátottsága is átlag feletti, de még szignifikánsan a romániai átlag alatt helyezkedik el. A kutatásban részt vevő TALIS országok közül Románia a 42. helyen szerepel, az európai országok közül csak Portugália található hátrányosabb helyzetben. Az öt évvel ezelötti adatokhoz képest viszont előmozdulás tapasztalható, ugyanis akkor (TALIS 2013) a digitális eszközellátottság hiánya 75,8\%-ot jelölt, azaz 26\%-kal magasabb arány volt tapasztalható. ${ }^{8}$ Az ARACIP ${ }^{9}$ 2018-as jelentésének függvényében (vö. Mihăilă és Paraschiva, 2020), amelyben 238 tanintézmény külső értékelését végezték el 43 indikátor alapján, a tanintézmények digitális eszközellátottsága egy ötfokú skálán ( 0 - elégtelen, 1 - elégséges, 2 - jó, 3 - nagyon jó, 4 kiváló) 2,46-os átlagot jelölt, amely nagy vonalaiban megegyezik a nemzetközi mérés 49,8\%-os értékével. Meg kell jegyezni, hogy a vidéki iskolák szignifikánsan alacsonyabb (város: 2,69, vidék: 2,21) digitális eszközellátottsággal rendelkeznek (Mihăilă és Paraschiva, 2020), márpedig Romániában - a 2018-as országos statisztikai adatok szerint - a legtöbb általános iskola vidéki környezetben található (vidék: 71,10 ; város 28,90 ). ${ }^{10}$

Ugyanez érvényes az internet ellátottságra vonatkozóan is, mely szintén szükségszerü a digitális- és távoktatás során. A 2013-as állapothoz viszonyítva (TALIS 2013: 64,1\%) majdnem a felére csökkent (TALIS 2018: 36,2\%) az internethez való hozzáférés hiánya. Meg kell jegyezni, hogy a jelenlegi adat az iskola internet ellátottságára utal, tehát még mindig nem tudjuk, hogy a tanulók és a tanárok otthoni

\footnotetext{
${ }^{7}$ Digitális eszköz alatt a kérdőív elsősorban a szoftverekre, számítógépekre, táblagépekre, interaktív táblákra stb. utal.

${ }^{8}$ OECD, TALIS 2013 adatbázis: Table 2.19 [http://dx.doi.org/10.1787/888933043112]

9 Agenția Română de Asigurare a Calității în Învățământul Preuniversitar. Magyarul: Romániai Közoktatás Minőségét Biztosító Ügynökség [www.aracip.eu]

${ }^{10}$ [http://statistici.insse.ro:8077/tempo-online/\#/pages/tables/insse-table] Institutul Național de Statistică. A TEMPO-Online statisztikai adatbázisát használtam: SCL101B (Unități școlare pe niveluri de educație, medii de rezidență, macroregiuni, regiuni de dezvoltare și județe).
} 
internethozzáférése mennyire biztosított a digitális/ távoktatáshoz. ${ }^{11}$ Romániában nemcsak az Információs és Kommunikációs Technológiákkal (a továbbiakban IKT) támogatott tananyagokból, hanem például a tankönyvekböl is szignifikánsan magasabb az ellátottsági hiány, ahogyan a tantermekből, infrastruktúrából stb. Kiemelendő az a tény is, hogy a sajátos nevelési igényü (a továbbiakban SNI) tanulók oktatásához szükséges szaktanárok hiányát kivéve a hátráltató tényezők rangsorát nem az emberi erőforrás, hanem az anyagi források adekvát hiánya képezi. A nemzetközi kutatások arról számolnak be, hogy az iskola eredményességéhez és a tanulók teljesítményéhez közvetett vagy közvetlen módon úgy az emberi, mind az anyagi források megléte/hiánya pozitív/negatív módon járul hozzá (Rivkin - Hanushek - Kain, 2005; Gil-Flores - Rodríguez-Santero - Torres-Gordillo, 2017). Ha a PISA mérésekben jól/kevésbé jól teljesítő országokat a TALIS mérésben adekvát eszközellátottsággal rendelkező/hiánnyal küszködő országok eredményeivel hasonlítjuk össze, akkor pozitív korrelációt találunk. Elegendő itt néhány országra utalnunk: pozitív Finnország, Szingapúr, Szlovénia stb.; negatív - Kolumbia, Brazília, Szaúd-Arábia stb. ${ }^{12}$

Köztudott, hogy a technológia megléte önmagában nem biztosítja az oktatás hatékonyságát, az ugyanis csak annyiban jó, amennyiben azt (szakszerủen) használják is. Így a továbbiakban olyan kérdést vizsgálok meg, amely arra kérdezett rá, hogy a tanárok a tanítási gyakorlatuk során milyen oktatási módszereket alkalmaznak.

2. táblázat. A tanteremben alkalmazott oktatási módszerek $(\%)^{13}$

\begin{tabular}{|l|c|c|}
\hline & $\begin{array}{c}\text { Megengedi, hogy a tanulók IKT-eszközöket } \\
\text { használjanak a projektjeikhez vagy az órai } \\
\text { munkához }\end{array}$ & $\begin{array}{c}\text { Olyan projekteket ad a tanulóknak, } \\
\text { amelyek elkészítése legalább egy hetet } \\
\text { vesz igénybe }\end{array}$ \\
\hline TALIS (48) & 51,3 & 30,5 \\
\hline OECD (31) & 52,7 & 28,6 \\
\hline EU (23) & 46,1 & 26,1 \\
\hline RO & 56,2 & 33,7 \\
\hline HU & 48,1 & 9,9 \\
\hline
\end{tabular}

Forrás: OECD, TALIS 2018 (BTGINTT3) - egyéni számítás és szerkesztés

Chi-négyzet próba. Megj.: $p \leq 0,001$.

A kérdőív 16 itemet tartalmazott, amelyet a TALIS kidolgozói négy faktorba (kategóriába) soroltak: fegyelem és rend fenntartása, tanítási és tanulási célok meghatározása, kognitív aktiváció, önállóan végzett tevékenységek serkentése. ${ }^{14} \mathrm{~A}$ fenti táblázatban (vö. 2. táblázat) nevesített két item az utolsó modern módszerek/ önállóan végzett tevékenységek serkentése - faktor részét képezi. Azért lényeges ennek a kérdésnek a vizsgálata, mert az egyik napról a másikra digitális oktatást/ távoktatást meghirdető oktatáspolitikának csak akkor lehetett maradéktalanul eleget tenni, ha a tanárok és a tanulók már korábban is használták a tanítási-tanulási folyamatban az IKT-val támogatott eszközöket a tanórai munkához, avagy a projektpedagógiát, a kollaboratív, a problémaalapú stb. módszereket is alkalmazták. Márpedig azt látjuk, hogy nemzetközi szinten a tanárok fele alkalmazta az oktatási tevékenysége során az IKT-val támogatott tanítás-tanulást, és még ennél is kevesebben (kb. 30\%-a) alkalmazták a modern (tanulóorientált) oktatási módszereket, amelyek kedveznek a távoktatásnak (Vieluf - Kaplan - Klieme - Bayer, 2012). Románia mindkét esetben átlagon felüli értéket képvisel,

\footnotetext{
${ }^{11}$ Az oktatási minisztérium (MEC) által közölt becslési adatok szerint kb. 250.000 tanuló, míg a Tanulók Országos Tanácsa (CNE) által közölt adatok szerint kb. 900.000 tanuló nem rendelkezett az online oktatás során digitális eszközzel.

12 OECD, TALIS 2018 adatbázis: Table I.3.63. [http://dx.doi.org/10.1787/888933932399]; OECD, PISA 2018 $\begin{array}{lllll}\text { adatbázis: Table } & \text { I.4.1, Table } & \text { I.4.2, } & \text { Table I.4.3 } & \text { [https://doi.org/10.1787/888934028235; }\end{array}$ https://doi.org/10.1787/888934028254]

13 A TALIS 2018 tanári kérdőív 42. kérdésének o) és p) itemei. A négyfokú skála 3. és 4. értékeit (gyakran- és mindig használom) összevontam.

${ }^{14}$ OECD, TALIS 2018 adatbázis: Table I.2.1. [http://dx.doi.org/10.1787/888933931905]
} 
míg Magyarország átlag alattit, sőt meglepően alacsony (szignifikáns eltérés) a projektmódszer alkalmazása terén $(9,9 \%$ - vö. 2. táblázat).

Tehát az önállóan végzendő tevékenységek serkentése nem valósult meg mindezidáig, így a távoktatás hatványozottan nehéz mind a pedagógusok, mind a tanulók számára, azaz azok számára volt az adott szituáció áthidalható, akik korábban is alkalmazták, ösztönözték a tanulókat akár a digitális eszközök bevonására, akár a projektmunkára. Az a véleményem, hogy a közeljövőben is csak akkor fog hatékonyan müködni akár a digitális/távoktatás, akár a tanórai oktatás, ha a tanárok és a tanulók a modern oktatási módszereket (digitális pedagógia, projektpedagógia stb.) beviszik a mindennapi pedagógiai gyakorlatukba. A kognitív aktiváció jellegü tevékenységekre a fent leírtak ugyanúgy vonatkoznak. Meg kell jegyeznem, hogy az elmúlt méréshez képest nemzetközi viszonylatban is szignifikánsan magasabb az IKT eszközöket tanítási gyakorlatuk során használó pedagógusok aránya Romániában (TALIS 2013: 26\%, TALIS 2018: 56,2\%), ugyanis az 30,2\%-kal növekedett. Hasonlóan magas arányú „fejlődés” Finnországban, Svédországban és Izraelben volt tapasztalható. Ugyanez a modern módszerek (pl. projektpedagógia) esetében is kijelenthető (TALIS 2013: 21,6\%, TALIS 2018: $33,7 \%$ ), ugyanis itt is $12 \%$-os növekedés konstatálható. ${ }^{15}$

A továbbiakban egyrészt azt a kérdést vizsgálom meg, hogy a pedagógusok a formális (tanár)képzésük során részesültek-e az IKT-eszközökkel támogatott tanítás-tanulás jellegü tartalommal, másrészt azt, hogy az elmúlt évben vettek-e részt IKT jellegủ szakmai továbbképzésen, majd végül azt, hogy milyen jellegü továbbképzésre tartanak igényt, aspirálnak a közeljövőben.

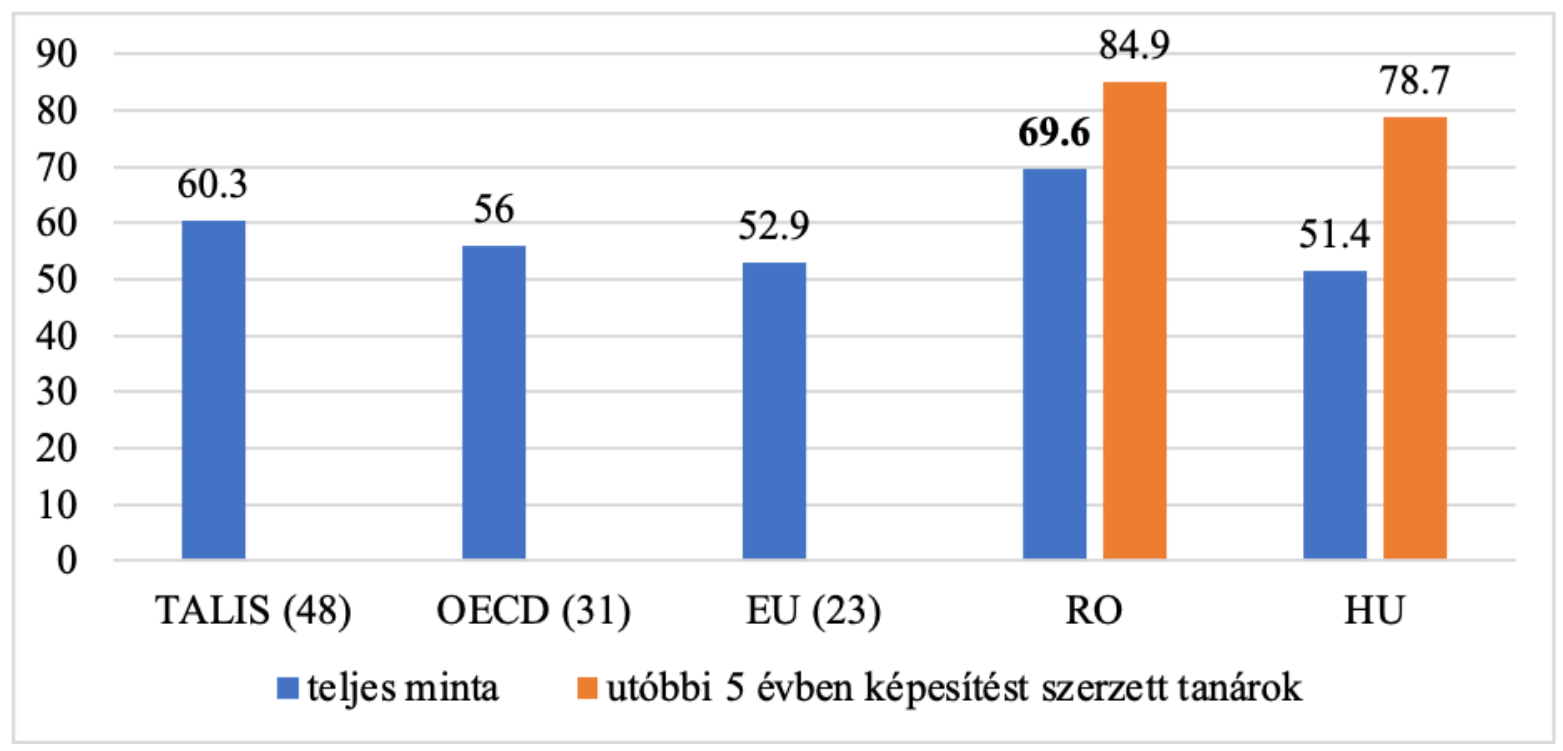

1. ábra. IKT eszközök használata tanítás céljából $(\%)^{16}$

Forrás: OECD, TALIS 2018 (BTGINTT3) - egyéni számítás és szerkesztés

Chi-négyzet próba. Megj.: $p \leq 0,001$.

Nem létezik még az Európai Unión belül, sőt még a bolognai folyamat sem körvonalazott egy egységes tanárképzési modellt és tartalmat, így az országonként eltérő rendszerrel és képzési kínálattal kerül megszervezésre (Kozma - Rébay - Ohidy - Szolár, 2014; Lim, 2013; Venter, 2008). Romániában a tanárképzés tartalma országosan egységes, központilag meghatározott tantervvel rendelkezik, amely több mint két évtizede változatlan (Szabó-Thalmeiner, 2006; 2007; Kovács Fóris-Ferenczi - Birta-Székely, 2009), bár abban szerepel egy IKT-s jellegű tárgy, amelynek elnevezése a „Számítógéppel támogatott oktatás” (Instruire asistată de calculator). Valószínúleg ezzel magyarázható, hogy Romániában szignifikánsan magasabb azon pedagógusok aránya akár az OECD,

\footnotetext{
${ }^{15}$ OECD, TALIS 2018 adatbázis: Table I.2.4. [http://dx.doi.org/10.1787/888933931924

${ }^{16}$ A TALIS 2018 tanári kérdőív 6. kérdésének h) itemét tartalmazza. Az „utóbbi 5 évben képesítést szerzett tanárok” változó a TALIS, OECD, EU adatok esetében hiányosak, így nem lehet azt megjeleníteni.
} 
EU, de Magyarország tanárképzési tantárgyi curriculumához viszonyítva, akik a képzésük során már tanulták az IKT az oktatásban jellegü tárgyat. Az összehasonlításból arra is válasz érkezett, hogy a lekérdezést megelöző öt évben a tanárképzést befejező, oklevelet szerző pedagógusok IKT eszközök pedagógiai célú használatának aránya szignifikánsan magasabb (Románia esetében kb. 15\%-kal, míg Magyarország esetében kb. 27\%-kal - vö. 1. ábra). Tehát a fiatalabb generáció már a formális képzése során részesül a digitális oktatáshoz szükséges ismeretekkel.

3. táblázat. Az IKT-eszközök tantermi használata és az IKT-eszközök tanárképzés során elsajátított készség közti összefüggés vizsgálata

\begin{tabular}{|l|c|c|c|}
\hline & $\begin{array}{c}\text { IKT-eszközök használata tanítás } \\
\text { céljából tárgy tartalmazta a } \\
\text { tanárképzés tartalmát }\end{array}$ & nem & tanítási tapasztalat \\
\cline { 2 - 4 } & $\operatorname{Exp}(\mathrm{B})$ & $\operatorname{Exp}(\mathrm{B})$ & $\operatorname{Exp}(\mathrm{B})$ \\
\hline Románia & $1,556 * * *$ & $1,483 * * *$ & $1,011 * *$ \\
\hline Magyarország & $1,632 * * *$ & 1,220 & 1,006 \\
\hline EU (23) & $1,498 * * *$ & $1,080 * *$ & $1,008 *$ \\
\hline OECD (31) & $1,468 * * *$ & $1,181 * *$ & $1,006 *$ \\
\hline TALIS (48) & $1,530 * * *$ & $1,200 * *$ & $1,006 *$ \\
\hline
\end{tabular}

Forrás: OECD, TALIS 2018 (BTGINTT3) - egyéni számítás és szerkesztés

Bináris logisztikus regresszió-analízis.

Megj.: *p ${ }^{*} 0,05 ; *{ }^{*} p \leq 0,01 ; * * * p \leq 0,001$.

Az $\operatorname{Exp}(B)$ esélyhányados azt jelzi, hogy a magyarázó változó milyen mértékben van hatással egy kategoriális változóra. Ha az érték 1, akkor nincs hatás; ha az érték 1 fölötti, akkor egyenes irányú (pozitív); ha az érték 1 alatti, akkor fordított irányú (negatív) hatásra számíthatunk.

Független változó: ,gyakran” és „,mindig” megengedi, hogy a tanulók IKT-eszközöket használjanak a projektjeikhez, vagy az órai munkához. Dummy változó: referenciaérték a ,soha vagy majdnem soha” és „,alkalmanként” megengedi, hogy a tanulók IKT-eszközöket használjanak a projektjeikhez, vagy az órai munkához. Függö változók: 1. IKT-eszközök használata tanítás céljából tárgy tartalmazta a tanárképzés tartalmát. Dummy változó: referenciaérték az IKT-eszközök használata tanitás céljából tárgy nem tartalmazta a tanárképzés tartalmát. 2. Tanár neme. Dummy változó: referenciaérték a férfi. 3. Tanítási tapasztalat - évek száma.

A következőkben arra vagyok kíváncsi, hogy összefüggés tételezhető-e a tanárképzés során az IKT eszközökkel való oktatás tárgyban részesült tanárok és az oktatási folyamata során tanulóknak IKTeszközök használatát tanulás céljából serkentő változók között? A fenti regresszióelemzés arra mutat rá, hogy nagyon lényeges a tanárképzés tartalma, amely merőben hozzájárul az oktatás minőségéhez (Fraillon - Ainley - Schulz - Friedman - Gebhardt, 2014; Krumsvik, 2008). Azt láthattuk, hogy azok a tanárok, akik a képzésük során jártasságra tettek szert az IKT eszközök használatában, azok a tanítási folyamatuk során nagyobb eséllyel (1,556-os esélyhányadossal) adnak a tanulók számára olyan feladatokat, amelyek ezt támogatják. Románia esetében szignifikáns kapcsolatot találtunk még a nem esetében is, azaz a nők esetében 1,48-cal nagyobb az esély, hogy az IKT eszközöket a tanítási folyamatban alkalmazzák, ahogyan azt is, hogy a fiatalabb generáció magabiztosabban alkalmazza a modern eszközöket és módszereket, valamint nagyobb eséllyel (1,011-es esélyhányadossal) bátorítja a tanulókat annak használatára. Kétségkívüli az innovatív oktatási módszerek, eszközök és értékelési módok, mint például a blended learning: fordított tanterem/tanulás (flipped classroom/ learning), a játékosítás (gamification), a gamification alapú értékelés, az IKT eszközökkel támogatott projektek, az informatikai/számítógépes gondolkodás (computational thinking), a testi érzékelésen keresztuil megvalósuló tanulás (embodied learning), a BYOD-modell, a digitális történetmesélés (digital storytelling), a társasjáték-pedagógia stb., nemcsak a digitális oktatás/ távoktatás, hanem a tantermi oktatásba való inkadrálása (Paniagua és Istance, 2018).

A következő lépésben azt vizsgáltam meg, hogy milyen szakmai fejlődést elösegítő továbbképzésen vettek részt a pedagógusok az elmúlt évben, illetve milyen jellegü képzések felé aspirálnak. A kérdés 14 tevékenységet nevesített, amelyek közül a lenti diagramon (vö. 2. ábra) csak az IKT-készségeket elősegítő továbbképzéseket ábrázoltam. Látható, hogy a romániai tanárok szignifikánsan alacsonyabb arányban vettek részt ilyen képzéseken, mint a nemzetközi átlag, vagy a referenciaként hozott 
Magyarország is. Az alacsony arányszám kapcsán felmerül bennem a kérdés, hogy vajon amiatt, mert nem volt rá szükség, vagy amiatt, mert nem állt a pedagógusok rendelkezésére.

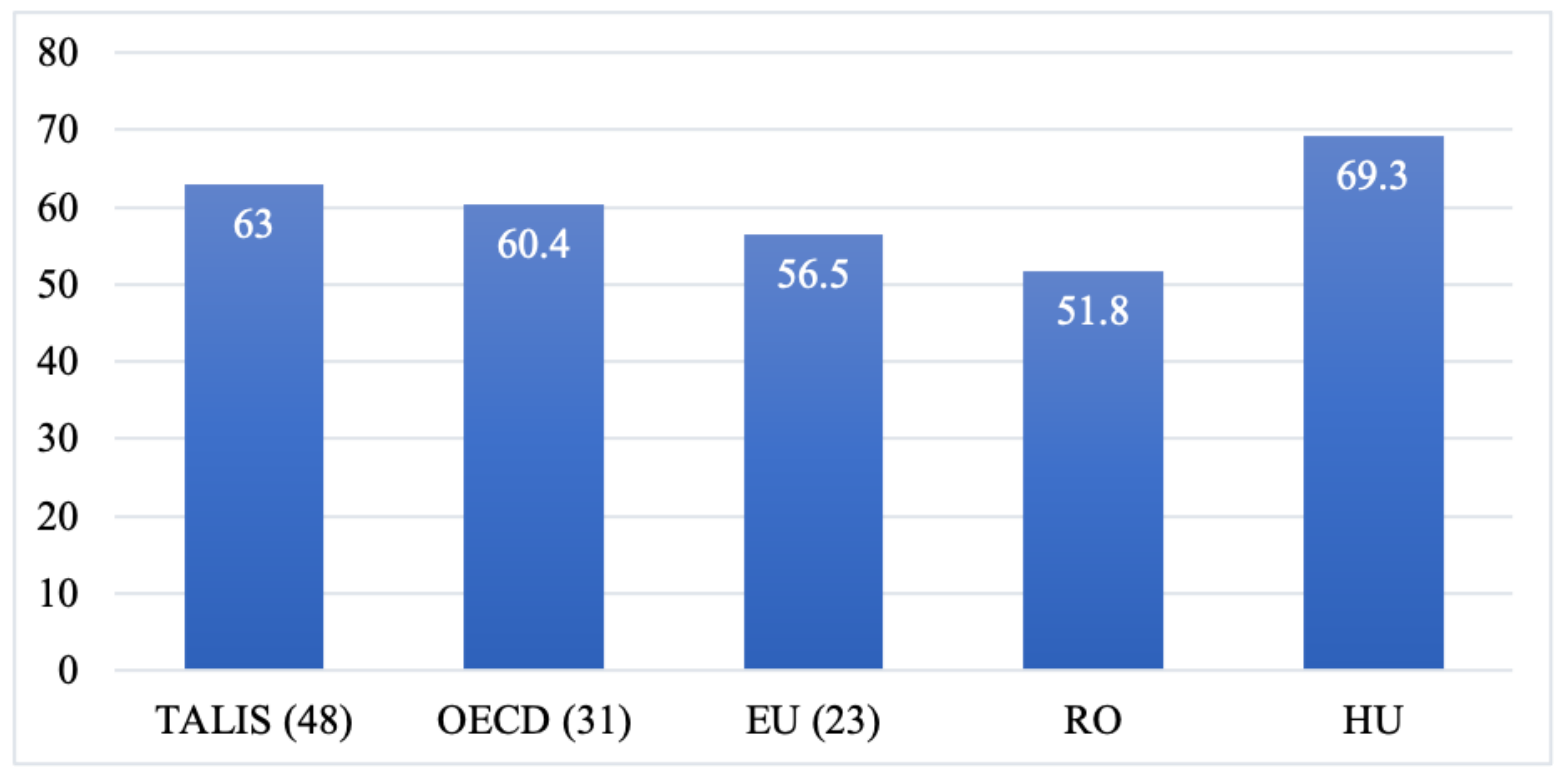

2. ábra. Az IKT-készségeket elősegítő továbbképzések $(\%)^{17}$ Forrás: OECD, TALIS 2018 (BTGINTT3) - egyéni számítás és szerkesztés Chi-négyzet próba. Megj.: p $\leq 0,001$.

A fentebb ismertetett eredmények értelmezését a következő kérdés eredményei jobban árnyalják, ugyanis az sokkal mérvadóbb, hogy milyen jellegü aspirációik vannak a tanároknak a szakmai képzésüket illetően. A lenti táblázat (vö. 4. táblázat) alapján kijelenthetjük, hogy a SNI tanulók tanítása iránti továbbképzésre van a legnagyobb igény úgy nemzetközi, mind országos szinten. Ez érthető is, hiszen - legalábbis Romániában - a tanárképzés tartalmában nem szerepel ilyen jellegü kötelezö tantárgy. Ellenben a közoktatási rendszerben egyre több SNI tanuló van jelen, akiknek a tanításához a pedagógusok nem rendelkeznek adekvát módszerekkel, képzéssel. A nemzetközi adatok értelmében a második helyen az IKT jellegü készégek fejlesztésére van igény, amely fejezetünk központi témája is. Tehát a tanárok folyamatos szakmai fejlődésében érzékelhető az IKT eszközök oktatási célú használatának kulcsszerepe. Romániában a fontossági sorrendben a negyedik helyen szerepel, valószínűleg a már fentebb említett indok miatt, ugyanis a romániai tanárképzés tartalmazza az IKT-eszközök használata az oktatásban tantárgyat. A nevesített 14 opció közül a multikulturális/többnyelvű környezetben való tanítás és más kultúrákból/országokból érkező emberekkel történő kommunikációs jellegű továbbképzési tematikák folytatják a lajstromot. A táblázatban még azokat nevesítettem, amelyekre a legkevésbé aspirálnak a tanárok, olyanok mint az iskolai szervezés és adminisztráció, a tananyag ismerete, tantárgyakhoz kapcsolódó tudás stb.

4. táblázat: A tanárok továbbképzési aspirációi $(\%)^{18}$

\begin{tabular}{|l|c|c|c|c|c|}
\hline & TALIS & OECD & EU & RO & HU \\
\hline SNI tanulók tanítása & 23,9 & 22,2 & 21 & $\mathbf{3 5 , 1}$ & 22 \\
\hline
\end{tabular}

\footnotetext{
${ }^{17}$ A TALIS 2018 tanári kérdöív 23. kérdésének e) iteme.

18 A TALIS 2018 tanári kérdőív 27. kérdése. A négyfokú skála 3. és 4. értékeit (mérsékelt- és magas szintű igény) összevontam. A kérdés 14 itemet tartalmaz, melyek közül csak a leginkább- és a legkevésbé igényelt szakmai továbbképzéseket jelenítettem meg.
} 


\begin{tabular}{|c|c|c|c|c|c|}
\hline IKT készségek az oktatásban & 20 & 17,7 & 16,1 & 21,2 & 20,5 \\
\hline $\begin{array}{l}\text { Tanítás multikulturális } \quad \text { vagy } \\
\text { környezetben }\end{array}$ & 16,4 & 15 & 13,4 & 27,1 & 12,6 \\
\hline $\begin{array}{l}\text { Kommunikáció más kultúrákból vagy országokból } \\
\text { származó emberekkel }\end{array}$ & 13,4 & 11,1 & 9,9 & 27,4 & 9,8 \\
\hline \multicolumn{6}{|l|}{ 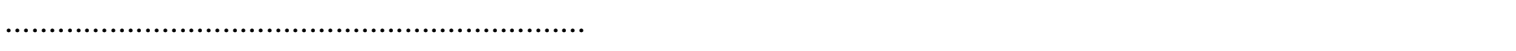 } \\
\hline $\begin{array}{l}\text { A tantárgyi terület(ek) tanításához kapcsolódó } \\
\text { pedagógiai kompetenciák }\end{array}$ & 12,8 & 10,2 & 7,6 & 10,1 & 8,2 \\
\hline $\begin{array}{l}\text { A tantárgyi terület(ek)hez kapcsolódó tudás és } \\
\text { megértés }\end{array}$ & 11,8 & 9,4 & 6,1 & 8,7 & 6,5 \\
\hline A tananyag ismerete & 10,8 & 7,6 & 5 & 10,5 & 5,4 \\
\hline Iskolai szervezés és adminisztráció & 9,2 & 7,5 & 6,3 & 14,3 & 4,4 \\
\hline
\end{tabular}

Forrás: OECD, TALIS 2018 (BTGINTT3) - egyéni számitás és szerkesztés Chi-négyzet próba. Megj.: $p \leq 0,001$.

\section{Diszkusszió}

Annyi bizonyos, hogy az IKT-eszközökkel támogatott tanítás-tanulás-értékelés ön- és továbbfejlesztésére a jelenlegi szituációban még inkább nagyobb szükség van, föképp a pedagógusoknak, tanintézményvezetőknek, oktatásügyi szakértőknek, mint korábban. A tanárok továbbképzése még csak a digitális átállás egyik elemét képezi. A digitális átálláshoz az IVSZ (2017) szerint legalább négy konstitutív elemnek kell teljesülnie: a) intézményszintű elköteleződés - ahol a tanintézményvezető a digitális pedagógia iránt elkötelezett és felkészült, ahogyan a tantestület is. Van egy víziójuk, és a digitális technológiát, pedagógiát beépítették az iskola pedagógiai programjába, intézményi fejlesztési tervébe. A World Vision (2020) legfrissebb kutatása, amelyet a vidéki iskolák körében végeztek, többek között arról tanúskodik, hogy a tanintézményvezetők $87 \%$-a szerint az online oktatást nem szabad tovább folytatni. b) második elengedhetetlen eleme a digitális eszközök (technológia) megléte, amelyekben az oktatáspolitika a szükségben levő iskolákat, tanulókat, tanárokat támogatni tudja: laptop, tablet, PC, WiFi. A Romániára szelektált eredmények arról tanúskodnak, hogy tízből öt iskola nem rendelkezik a digitális oktatáshoz szükséges eszközellátottsággal (laptop, PC, tablet). Ebben az esetben alternatív megoldás lehet a BYOD (Bring Your Own Device - Hozd magaddal a saját eszközöd) modell, amely bevett módszer a nemzetközi szférában. Ugyanakkor háromból egy iskola nem rendelkezik szélessávú internet hozzáféréssel. c) digitális módszertan/ digitális pedagógia, amelynek során fơképp a tanárok fejlesztik saját digitális írástudásukat, korszerüsítik a pedagógiai módszertárukat, oktatási-technikai jellegü ismereteiket. Mindehhez szorosan kapcsolódik - ahogyan azt a fentiekben már jeleztük - olyan jellegü feladatok, módszerek alkalmazása a tanulók körében, amelyek az önállóan végzendő tevékenységeket serkentik. Mindezek tanuló-orientáltak, az aktív tanulást támogatják, a kollaborációra építenek a digitális eszközhasználat alkalmazásával. Láthattuk, hogy a tanárok fele még nem alkalmazta oktatási tevékenysége során az IKT-eszközökkel támogatott tartalmakat és módszereket, azaz nem voltak, nincsenek felkészülve a digitális oktatásra. d) a digitális tantermek létrehozása és alkalmazása, amelyek az online tanulási környezetet teremtik meg. Ebben több iskola is lépett az elmúlt időszakban, egyesek a Google Tanterem, mások a Microsoft Teams, ismét mások az Edmodo, Canvas, Powerschool, vagy egyéb online teret, tudásmenedzsment (LMS) felületet hoztak létre a közös tanulásra-tanításra.

A TALIS legfrissebb nemzetközi vizsgálatának másodelemzése alapján a romániai tanárok többnyire a predigitális korból származnak, viszont állandó önképzési folyamatnak vetik alá magukat, így képesek a megújulásra, a változásra, az innovációra. A megvizsgált adatok alapján az iskolák, a tanulók, és a pedagógustársadalom mintegy fele lehetett szakmailag (digitális pedagógia), eszközellátottság, oktatási innováció tekintetében felkészülve a digitális átállásra, amely csak részben valósult meg. Ebböl következik, hogy a közeljövőben szükséges lesz a pedagógustársadalom másik felének is az IKT-s készségek az oktatásban való felhasználásának a fejlesztésére, digitális kompetenciájuk fejlesztésére, ahogyan az a szakmai továbbképzési aspirációkban is megnyilvánul. Mindezek mellett ugyanúgy szükség van és lesz adekvát oktatási szoftverekre és megfelelő iskolai, tanulói 
infrastruktúrára, ahogyan a digitális tartalmak egymással, egymás közti megosztására, tanári együttmüködésre. A jelenlegi áldatlan szituáció okozta átállás, nevezetesen a digitális oktatásra, az innovatív típusú tanároknak, iskoláknak, intézményvezetőknek kedvezett.

\section{Irodalomjegyzék}

Ainley, J., Carstens, R. (2018): Teaching and Learning International Survey (TALIS) 2018 Conceptual Framework. OECD Education Working Papers, 187. OECD Publishing, Paris.

Balázsi I., Vadász Cs. (2019): TALIS 2018. Összefoglaló jelentés. Oktatási Hivatal, Budapest.

Fraillon, J., Ainley J., Schulz, W., Friedman, T., Gebhardt, E. (2014): Preparing for Life in a Digital Age: The IEA International Computer and Information Literacy Study International Report. Springer International Publishing, Heidelberg.

Gil-Flores, J., Rodríguez-Santero, J., Torres-Gordillon J-J. (2017): Factors that explain the use of ICT in secondary-education classrooms: The role of teacher characteristics and school infrastructure. Computers in Human Behavior, 68, 441-444.

Informatikai, Távközlési és Elektonikai Vállalkozások Szövetsége (2017): Ajánlások a digitális pedagógia szakmai. és technológiai feltételrendszeréhez. https://dpmk.hu/wpcontent/uploads/2018/01/Ajánlások-a-digitális-pedagógia-feltételrendszeréhez.pdf

Kovács Z., Fóris-Ferenczi R., Birta-Székely N. (2009): A romániai oktatási rendszer. In Torgyik J. (szerk.): Oktatási rendszerek Európában. Krónika Nova Kiadó, Budapest, 136-152.

Kozma T., Rébay M., Ohidy M., Szolár É. (2014): The Bologna Process in Central and Eastern Europe. Springer Fachmedien Wiesbaden, Wiesbaden.

Krumsvik, R. (2008): Situated learning and teachers' digital competence. Education and Information Technologies, 13/4, 279-290.

Lim, S. (2013): Lehrerausbildung und Abstimmungsprobleme des Lehrermarkts. Springer Fachmedien Wiesbaden, Wiesbaden.

Mihăilă, C., Paraschiva, G. A. (2020): Raport privind realizarea activităților de evaluare externă periodică a calității in 238 de unități de învățământ preuniversitar de stat. http://beta.aracip.eu/Despre\%20ARACIP/Despre\%20ARACIP/Rapoarte\%20si\%20studii

OECD/Eurostat/UNESCO Institute for Statistics (2015): ISCED 2011 Operational Manual: Guidelines for Classifying National Education Programmes and Related Qualifications. OECD Publishing, Paris.

OECD (2019): TALIS 2018 Results (Volume I): Teachers and School Leaders as Lifelong Learners. OECD Publishing, Paris.

OECD (2020): TALIS 2018 Results (Volume II): Teachers and School Leaders as Valued Professionals. OECD Publishing, Paris.

Paniagua, A., Istance, D. (2018): Teachers as Designers of Learning Environments: The Importance of Innovative Pedagogies. Educational Research and Innovation. OECD Publishing, Paris.

Rivkin, S. G., Hanushek, E. A., Kain, J. F. (2005): Teachers, schools, and academic achievement. Econometrica, 73/2, 418-458.

Roxana M. et al. (2019): TALIS 2018. Studiul internațional OCDE privind predarea și învățarea. Centrul Național de Evaluare și Examinare, București.

Roxana M. et al. (2020): Raport Național TALIS 2018. Analiza mediului educațional din România. Centrul Național de Evaluare și Examinare, București. 
Szabó-Thalmeiner N. (2006): Kompetencia-alapú pedagógusképzés Romániában (1). Magiszter, 3-4, 20-35.

Szabó-Thalmeiner N. (2007): Kompetencia-alapú pedagógusképzés Romániában (2). Magiszter, 1, 37 45.

Tódor I. (2017): Egy felekezeti iskola tanárai körében végzett felmérés és a nemzetközi mérések tanúságai. In Bacskai Katinka (szerk.): A felekezeti oktatás új negyedszázada. Tanulmányok Pusztai Gabriella tiszteletére. Debreceni Egyetemi Kiadó, Debrecen, 158-176.

Venter Gy. (2008): A pedagogikum tartalma az európai tanárképzésben - a 90-es évek. Élmény '94. Bt., Nyíregyháza.

Vieluf, S., Kaplan, D., Klieme, E., Bayer S. (2012): Teaching Practices and Pedagogical Innovations: Evidence from TALIS. OECD Publishing, Paris.

World Vision România (2020): Bunăstarea copilului din mediul rural în perioada pandemiei. https://worldvision.ro/wp-content/uploads/2020/08/Infografice_Raport_Covid_ref.pdf

\section{Szerző}

Tódor Imre, Sapientia EMTE, Tanárképző Intézet, Csíkszereda; középiskolai tanár, Márton Áron Főgimnázium, Csíkszereda. E-mail: imretodor@gmail.com 
